\section{ЭКОНОМИКА}

УДК 332.012.2; 338.242.4; 339.9.012

\section{МИРОСИСТЕМНЫЙ ПОДХОД К КЛАССИФИКАЦИИ МОДЕЛЕЙ ГОСУДАРСТВЕННОГО ПРЕДПРИНИМАТЕЛЬСТВА}

\author{
И. О. Пугачёв \\ аспирант кафедры экономической теории и национальной экономики, \\ Саратовский государственный университет \\ E-mail: ilya_ov@mail.ru
}

Введение. Модель государственного предпринимательства обусловливается историческими условиями развития, географическим положением и национальной спецификой стран. Методика исследования. Государственное предпринимательство играет ключевую роль в концепции миросистемного анализа. Модель государственного предпринимательства определяет место государства в экономической системе и обусловлена позицией страны в рамках международного разделения труда по оси: держава-гегемон - центр - полупериферия - периферия. Результаты исследования. Европейская модель государственного предпринимательства - модель центра миросистемы. Она основана на условиях справедливого распределения доходов между государством, бизнесом и домашними хозяйствами. США как гегемон мировой экономики имеет модель государственного предпринимательства, основанную на получении доходов из внутренних и из внешних источников, подвергая монетарной эксплуатации остальные страны. Модель государственного предпринимательства стран периферии обеспечивает поставку хозяйственных ресурсов в регионы, занимающие более высокую иерархию в мировом разделении труда. Промежуточное место между американской моделью государственного предпринимательства и моделью стран периферии занимают модели стран полупериферии, в том числе российская модель экономики. Заключение. Россия по-прежнему остается полупериферийной страной с исключительно сильным влиянием на экономику государственного предпринимательства.

Ключевые слова: миросистемный анализ, модели государственного предпринимательства, европейская экономика, экономика США, экономика России.

\section{Введение}

В макроэкономических моделях система национальной экономики, как правило, определяется тремя важнейшими агрегированными хозяйствующими субъектами (секторами экономики): домашними хозяйствами, бизнесом и государством. Домашние хозяйства представляют все население страны, являются основной расходующей группой, субъектами личного потребления и сбережений, плательщиками индивидуальных налогов. Бизнес (сектор коммерческих предприятий и организаций, предпринимателей) выступает главным потребителем экономических ресурсов и производителем различных товаров и услуг. Государственный аппарат (государственный сектор) способен мобилизовать средства и организовать производство там, где другим экономическим субъектам это не под силу.
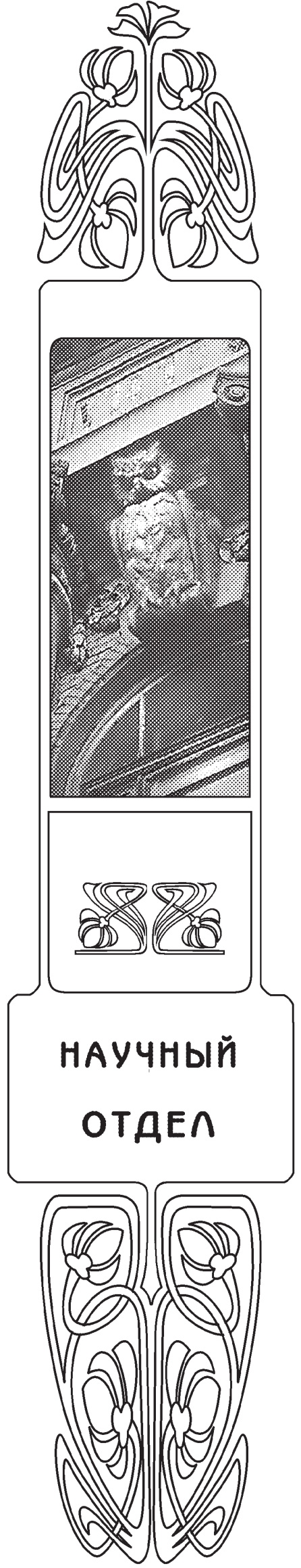
Хозяйственная активность государственной власти весьма разнообразна и имеет характерную предпринимательскую направленность, которую можно интерпретировать достаточно широко и многозначно. Приемлемым представляется нижеследующее развернутое определение.

Государственное предпринимательство деятельность государства, связанная с использованием казенной собственности и источников ее пополнения, направленная на расширение кругооборота контролируемых хозяйственных ресурсов. В сфере государственного предпринимательства находятся непосредственное ведение хозяйственных дел (казенное производство товаров и услуг, торговые монополии, займы и субсидии, текущее поступление и расходование средств бюджета) и реализация функций государственного управления (организация кредитно-денежного обращения, законодательное установление налоговых платежей, регулирование режима внешнеэкономических связей, регламентирование цен, тарифов, условий найма рабочей силы). Государственное предпринимательство охватывает спектр отношений с различной степенью эквивалентности: от безвозмездного присвоения и безвозвратного расходования части национального дохода на основании публичного права до обычных рыночных сделок в соответствии с гражданско-правовыми нормами. Объединяющим началом предпринимательства за казенный счет служит бюджет, гарантирующий господство государства в экономической системе страны [1, с. 8$]$.

Реализуя управленческие функции, государственный аппарат стремится выстроить такую инфраструктуру рынка, которая бы обеспечивала не только эффективную работу экономической системы, но и создавала дополнительный доход государству. Величина получаемого казенного дохода во многом зависит от источников формирования и способов распределения ренты прибыли, превышающей нормальный уровень дохода, возникающей от синергии растущей отдачи, инноваций и разделения труда, а также в силу благоприятных природных и географических условий в экономике.

Модель государственного предпринимательства определяется национальной спецификой стран: историческими условиями развития, совокупностью организационных форм, правовых, культурных, религиозных норм, идеологических установок, культурными традициями и географическим положением. Она формирует тип работника, трудовую этику, нормы права, национальные особенности экономики, вырабатывает парадигму мышления, экономические знания и практические навыки, образцы поведения, стимулы и регуляторы воспроизводства, а также определяет набор методов и инструментов, которые применяет правительство, реализуя экономическую политику, ее конечные результаты, долю ренты, поступающую в государственное распоряжение. Однако в экономической теории редко исследуются мотивы поведения государственного аппарата как хозяйствующего субъекта, который имеет свои специфические интересы [2, c. $31-40]$.

\section{Методика исследования}

Государство реализует свои интересы как в рамках национальной экономики, так и на международном уровне. Государственное предпринимательство играет ключевую роль в концепции миросистемного анализа, согласно которому международное хозяйство представляет собой «государственно организованный капитализм» рыночную систему в виде межгосударственного разделения труда [3, с. 230-353].

Интересный подход к исследованию роли государства в мировой экономике предложил И. Валлерстайн, утверждая, что наша межгосударственная система эволюционировала как надстройка капиталистического, определяла специфику современного государства и современной межгосударственной системы [4, с. 389].

Деятельность государства в народном хозяйстве собственной страны и во внешнеэкономической сфере обусловлена политической организацией мировой экономики как межгосударственной системы. Политико-экономические цели государственной власти определяются свойствами капиталистического мира-экономики: стремлением его субъектов к присвоению прибавочной стоимости и бесконечному накоплению каптала, политическим влиянием на уровень цен (капитала, потребительских товаров и труда), устойчивой поляризацией социальных слоев населения и регионов [4, с. 403].

Мировой рынок функционирует в режиме конкуренции и воспроизводит неравенство и иерархию его участников. Формируются три структурные позиции - сердцевина (центр), периферия и полупериферия. Кроме них в сердцевине мира-экономики одна страна занимает лидирующее положение гегемона.

Понятие гегемонии в межгосударственной системе описывает ситуацию соперничества между ведущими странами, в ходе которого одна держава оказывается первой среди равных. Она может навязывать свои правила и желания в экономической, политической, военной, дипломатической и даже культурной сферах. Материальная основа такой мощи коренится в возможностях 
предприятий, расположенных на территории державы, более эффективно действовать во всех трех основных экономических сферах - аграрнопромышленной, торговой и финансовой; причем не только на мировом рынке в целом, но и на внутренних рынках конкурирующих держав $[4$, c. 97$]$.

Опираясь на разницу в мощи государственных машин, сильные страны сердцевины навязывают неравный обмен периферийным регионам на таких условиях, чтобы добавочная стоимость доставалась им, а не периферии, т.е. странам слабым. Прибыльность хозяйственной деятельности связана со степенью ее монополизации. Ядру миросистемы свойственны производственные процессы, контролируемые квазимонополиями. Периферии остаются конкурентные процессы и товары, обмен которых осуществляется в худших по сравнению с квазимонополиями условиях. Поэтому наблюдается постоянный поток прибавочной стоимости от производителей периферии к производителям ядра.

Главная забота стран полупериферии - не скатиться в периферию, а еще лучше приблизиться к ядру. Обе задачи требуют серьезного участия государства в делах мирового рынка. Именно полупериферийные государства активно и публично проводят протекционистскую политику, надеясь таким образом защитить свое производство от конкуренции более сильных фирм извне и увеличить эффективность местных производителей, чтобы им было проще конкурировать на внешних рынках [5, с. 66, 93, 96].

Если на международном уровне борьба за ресурсы мировой экономики идет между государствами и каждый стремится «забраться» по лестнице международной иерархии как можно выше с целью получения большей части дохода, то в рамках национальной экономики разворачивается иная борьба. Различные статусные группы стараются постоянно изменять, с учетом собственных интересов, или уменьшать «власть» государства в желанных политико-экономических аспектах. Такие попытки изменить соотношение сил исходят из понимания, что преобразования должны помогать определенной группе в извлечении прямой или косвенной выгоды.

Величина получаемого дохода во многом зависит от модели государственного предпринимательства, т.е. от формы распределения властных полномочий между экономическими субъектами (агентами накопления), складывающейся на основе исторических условий развития экономики, культурных традиций общества, позиции страны в международном разделении труда, источников формирования и способов распределения доходов. Черта, которая позволяет различать модели государственно предпринимательства, заключается не в наличии определенных социально-экономических или государственно-правовых институтов, а в их комбинации в различных властных структурах.

Наблюдается соответствие между позицией страны в рамках международного разделения труда (центр - периферия) в разные исторические периоды (в рамках глобальной гегемонии одной страны) и ее моделью государственного предпринимательства, которая имеет особые, уникальные черты, собственные формы и методы государственного воздействия на макроэкономические пропорции и параметры, находящие свое отражение в динамике макроэкономической конъюнктуры. Модель государственного предпринимательства определяет место государства в экономической системе (хозяйственном механизме).

\section{Результаты исследования}

Историческая специфика формирования модели государственного предпринимательства на европейском континенте подробно рассмотрена в монографии норвежского ученого Э. С. Райнерта «Как богатые страны стали богатыми и почему бедные страны остаются бедными», а также в книге Джованни Арриги «Долгий двадцатый век: Деньги, власть и истоки нашего времени».

Становление европейской модели государственного предпринимательства - это, прежде всего, история преодоления экономической политикой устрашающих преград, поставленных на пути к богатству географией, климатом и культурой. Сочетание многообразия и соревнования в Европе порождало большое количество теоретических школ и технологических решений. Множество идей и их продуктов постоянно сравнивались между собой, формировались и развивались на рынках. Конкуренция городов-государств и национальных государств финансировала европейские изобретения, которые были побочным результатом состязания между народами и их правителями в военных успехах и роскоши. Как только стало ясно, что направление всех ресурсов на решение проблем в военное время приводит к изобретениям и инновациям, аналогичная модель управления стала применяться и в мирные будни. Европа быстро осознала, что для обрабатывающей промышленности характерна возрастающая отдача от масштабов производства и несовершенная конкуренция, что является залогом успешной конкуренции на мировом рынке. Поэтому развитие обрабатывающей промышленности решает все основные экономические проблемы: создает 
необходимые рабочие места, прибыль, большую заработную плату, базы для налогообложения и лучшее денежное обращение [6, с. 44-49].

Уже с периода ранней современности Европа видела связь между географическими, научными открытиями и инновациями, между развитием теории и практики. Первое богатство ведущих государств Европы обеспечивалось тройной рентой - тройной рыночной властью в экономической деятельности, которая отсутствовала в бедных странах. Это были промышленное производство, почти полная монополия в одном важном виде сырья, прибыльная международная торговля [6, с. 108].

Не удивительно, что первые государства-гегемоны зародились именно в европейской части света. Городам-государствам Генуе и Венеции на смену пришли Объединенные провинции (Голландия) в середине XVII в., Соединенное Королевство Великобритании в середине XIX в. В $\mathrm{XX}$ в. процессы мироэкономики развиваются под «флагом» американской гегемонии, а европейские страны расположились в центре мирового разделения труда. Соответственно, выделяются четыре системных цикла мировых процессов накопления капитала: генуэзский цикл XV - начала XVI в., голландский цикл конца XVI - третьей четверти XVIII в., британский цикл второй половины XVIII - начала XX в. и американский цикл, который начался в конце XIX в. и продолжается ныне [7, с. 44-45].

Сплав социальных идей, культурных традиций и стремление к экономическому прогрессу задали общий вектор развития капиталистической Европы. Экономический рост сопровождался равномерным разделением доходов между всеми экономическими субъектами (агентами накопления), формировались социальные институты, постепенно росло благосостояние населения, создавая высокий уровень потребления трудящихся классов, формировалась устойчивая база налогообложения.

Таким образом, можно констатировать, что европейская модель государственного предпринимательства основана на условиях реального (справедливого) распределения доходов между государством, бизнесом и домашними хозяйствами (рис. 1).

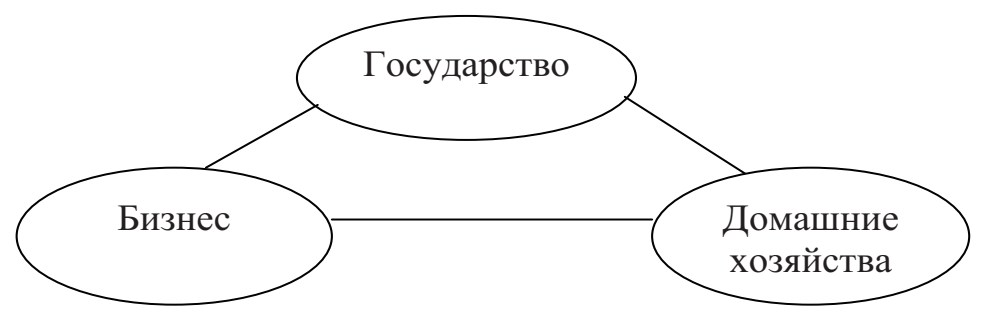

Рис 1. Европейская модель государственного предпринимательства

Европейской модели государственного предпринимательства присущи следующие черты: высокая доля государственных расходов в структуре ВВП, высокий коэффициент обновления основных фондов, инвестиционная привлекательность, низкая инфляция, высокий уровень заработной платы, сильные профсоюзы, развитая инфраструктура, в структуре экспорта преобладают готовые изделия.

Сегодня страны Евросоюза явно лидируют в ряде отраслей промышленности, которые иногда не причисляются к высокотехнологичному сектору, но являются важнейшей сферой приложения новых технологий. Фундаментом отраслевой структуры экономики является обрабатывающее производство, сочетающее высокий технологический прогресс и несовершенную конкуренцию, которой, как правило, сопутствует снижение издержек производства при увеличении его масштабов, что значительно повышает производительность труда, уровень заработной платы [6, с. 37].
Если история становления индустриального общества в Европе насчитывает по меньшей мере четыре столетия, то в США этот отрезок как минимум вдвое короче. Для современной американской экономики характерны следующие особенности: высокая производительность общественного труда, развитые рыночные институты, высокие денежные доходы, высокая покупательная способность населения, либерализация торговли и денежного рынка, высокий уровень потребления капитала, использование в экономике наукоемких технологий.

Соединенные Штаты Америки занимают центральное место в международном разделении труда. Будучи гегемоном мировой экономики, Америка задействует уникальную модель государственного предпринимательства, основанную на получении доходов как из внутренних источников, так и из внешних (мировой экономики), подвергая монетарной эксплуатации остальные страны. В становлении современной модели государственного предпринимательства амери- 
канцы прошли несколько этапов развития, связанных с фазами системных циклов накопления капитала [7, с. 281-282].

Идеология первых американских предпринимателей была исключительно фритредерской, а централизованная форма государственной власти с ее основными социально-экономическими функциями возникла как результат объединения штатов, передавших часть своих властных полномочий в центр [8, с. 140]. Федеральное правительство наряду с государственными мерами поддержки задействовало программы, выгоды от которых распределялись между всеми субъектами экономики. К таким программам относятся широкое распространение образования и усовершенствование методов повышения производительности в сельском хозяйстве; бурное развитие железных дорог, колонизация неосвоенных американских земель на основании «Акта о гомстедах»; были созданы необходимые предпосылки для формирования нового крупного центра накопления капитала [9]. Данные меры обеспечили минимальные возможности для всех американцев, способствовали развитию инфраструктуры, снижению транспортных издержек, расширению внутренних рынков.

Во время нарастающего системного хаоса, связанного с упадком Англии как мирового лидера в конце XIX - начале XX в., американская экономика стала центром притяжения международного капитала, способствовавшего обогащению и усилению страны, позволив ей вырваться на лидирующие позиции в мировом хозяйстве. Дж. Арриги отмечает: «Резкий рост американского богатства и власти в 1914-1945 годах, прежде всего, отражал защитную ренту, которой они пользовались благодаря необычайно привилегированному положению пространственной конфигурации капиталистического мира-экономики. И чем более турбулентной и хаотичной становилась мировая система, тем большую выгоду извлекали Соединенные Штаты из своих размеров, островного положения и прямого доступа к двум главным океанам мира-экономики» $[7$, с. 352].

Завершив континентальную интеграцию, в США приступили к транснациональной экспансии, экономика пережила системную перестройку, появилось множество вертикально интегрированных, бюрократически управляемых корпораций [7, с. 359], бизнес стал получать огромные доходы, постепенно «подбирая» власть по свой контроль.

После Второй мировой войны Соединенные Штаты стали важнейшей «мастерской» для союзников в послевоенном восстановлении Европы. Кроме того, впервые в американской истории требования на прибыль, создаваемую за рубежом, стали намного превосходить иностранные требования на прибыль, создаваемую в Соединенных Штатах, так чтобы профицит текущих счетов оказался намного выше активного сальдо торгового баланса.

В результате нового и более широкого роста торговли и профицита текущих счетов Coединенные Штаты, по сути, стали пользоваться монополией на мировые ликвидные активы. В 1947 г. их золотые резервы составляли 70\% от общих мировых резервов. Кроме того, избыточный спрос на доллары со стороны иностранных правительств и деловых кругов свидетельствовал о том, что американский контроль над мировыми ликвидными активами был гораздо сильнее, чем можно было предположить, глядя на такую экстраординарную концентрацию монетарного золота [7, с. 351].

Стагфляция 1970-х гг. на фоне кризисов перепроизводства свидетельствовала о нарастании финансовых диспропорций в мировой экономике. Падение добавленной стоимости в американской экономике на фоне обострившейся конкуренции на мировых рынках позволило переложить убытки капиталистов и государства на плечи рабочих.

В 1980 г. соотношение между средними зарплатами американских высших менеджеров по сравнению с заработной платой среднего работника в промышленности составляло 40:1; двадцать лет спустя - 475:1, т.е. в США топменеджеры зарабатывали в 20-30 раз больше, чем в европейских странах и Японии, и это несмотря на то, что европейские страны и Япония почти догнали или перегнали США по часовой производительности труда. Сопротивление рабочего класса в борьбе с капиталистами за равномерное распределение доходов в Соединенных Штатах ослабло больше, чем в других ведущих регионах. Это способствовало восстановлению прибыльности американской экономки в 1990-е гг. и позже [10, с. 186].

Ряд преобразований мировой финансовой системы, в частности, отмена «золотого стандарта», девальвация доллара 1969-1973 гг., помог США переложить груз ответственности на менее развитые страны, наводнив долларами мировую валютную систему [11].

С этого времени США стали задействовать схему монетарной эксплуатации «долларом». Она состоит из следующих звеньев: товарное кредитование США остальным миром; накопление долларовых резервов за рубежом; «связывание» их в американских «ценных» долговых бумагах; периодическое сжатие рынка облигаций и поощрение рынка акций, чтобы сместить центр 
тяжести на частный долг; обвал фондовой биржи, снижение общей задолженности; размещение получаемых монетарных дивидендов в прямые иностранные инвестиции, предназначенные для усиления американского капитала в ТНК; выкачивание через ТНК реальных ресурсов для вывоза в США. На этом один оборот завершается и стартует очередной [12, с. 21-31].

Как справедливо заметил М. В. Ершов: «Мировая экономика в большей мере зависит от состояния американской экономики, та в свою очередь от американского фондового рынка, а этот рынок в значительной степени определяется котировками 10-15 компаний, большинство из которых компании новой экономики» [13, с. 217]. Основным источником формирования доходов в американской модели государственного предпринимательства является финансовый капитал, большая часть которого достается частному бизнесу.

Уникальную модель государственного предпринимательства США как единственной «сверхдержавы» графически можно представить следующим образом (рис. 2):

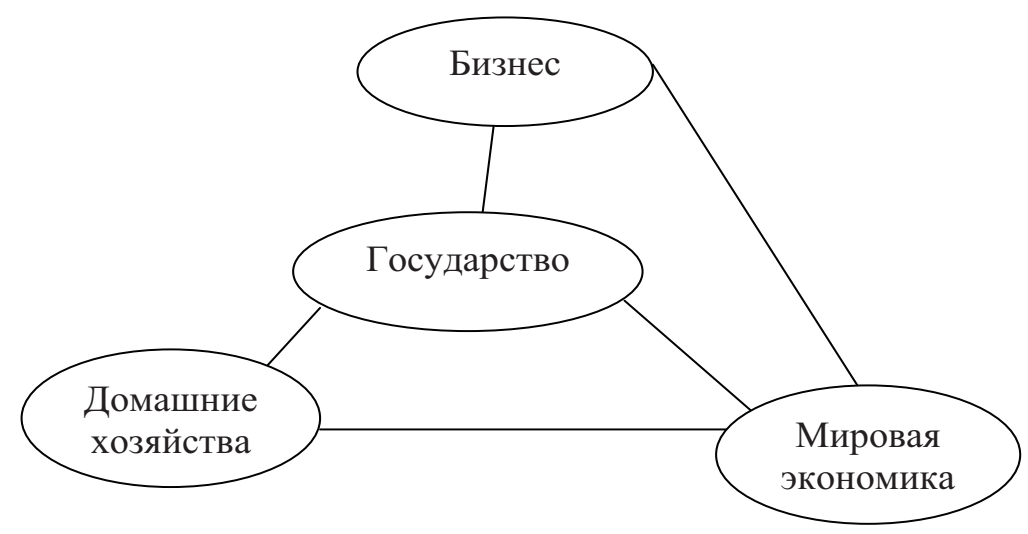

Рис. 2. Американская модель государственного предпринимательства

Если противопоставлять американской модели государственного предпринимательства как глобального гегемона модель государственного предпринимательства периферийных стран (страны Африки, Латинской Америки и Океании), то получим следующую структуру модели государственного предпринимательства (рис. 3):

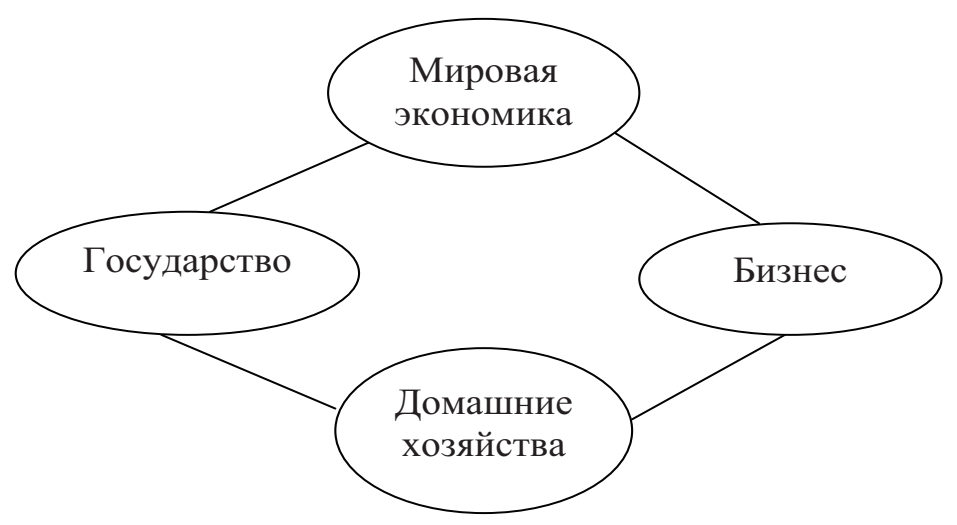

Рис. 3. Модель государственного предпринимательства стран периферии

Основной технологией политического влияния и проведения интересов американской гегемонии в странах периферии является установление контроля над институтами государственной власти различных стран и их демонтаж, замена международным правом и международными институтами. Ключевой инструмент - втягивание стран в сырьевую зависимость, деморализация или ослабление их правящей элиты. Делается это с помощью самых разнообразных неформальных структур и контактов. При этом активно используется политика ограничения на ввоз высокотехнологичных обрабатывающих и перерабатывающих производств. Ослабляя институты государ- 
ственной власти, политического, морального и культурного контроля, американская гегемония устраняет препятствия для свободного движения транснационального капитала.

Страны периферии являются поставщиками сырья и дешевой рабочей силы для стран, занимающих более высокую иерархию в мировом разделении труда. Технологическая структура таких стран характеризуется отсталыми технологиями, базирующимися на снижении отдачи от масштабов производства, низкими производительностью труда и доходами населения, слабой покупательной способность, трудоемким производством, в основном в экономике этих стран преобладает сельское хозяйство.

В рамках миросистемы технологическую структуру моделей государственного предпринимательства можно представить в следующем виде: «центр (индустриально-информационный мир) - полупериферия (традиционно индустриальный мир) - периферия (аграрный мир), включающий к тому же и разные промежуточные зоны» [14, с. 227].

Промежуточное место между американской моделью государственного предпринимательства и моделью стран периферии занимают государства полупериферии, в число которых входит и российская экономика.

Исторические корни российской модели государственного предпринимательства обусловлены особенностями формирования и эволюции национальных социокультурных и политико-культурных традиций России, менталитета населяющих ее народов. На это обратил внимание известный русский экономист М. И. Туган-Барановский: «Существует глубокое отличие условий русского хозяйственного развития от западноевропейского. Самым важным и основным из них является отсутствие в России стадии городского хозяйства» [15, с. 107-108]. Московское государство совершенно не знало того социального класса, который сыграл огромную и многообразную роль в истории Европы, - класса свободных ремесленников.

Истоки российской модели государственного предпринимательства восходят к временам Петра I. В Московской Руси, несмотря на значительное развитие крупной купеческой и мелкой розничной торговли, промышленность имела примитивный, кустарный характер и сохранила бы его еще надолго, если бы на сцену не выступил новый фактор - государство [16, с. 84-85].

В допетровской Руси не существовало промышленного капитализма, но был развит торговый капитализм. Купцы не обнаруживали наклонности захватить в свои руки производство, а предпочитали скупать, владея рынком, продукты труда мелкого производителя и держать ремесленника в полной зависимости от себя, не обращая его в наемного работника. Концентрация торгового капитала в допетровской Руси была вызвана не правительственными мероприятиями, а естественной эволюцией торговли, преимуществом крупной торговли перед мелкой. Этот-то торговый капитал и стал базисом крупного производства в эпоху Петра I [16, с. 80,86$]$.

Государственная поддержка крупной промышленности была обычным, естественным явлением в мировой практике. Меры Петра Великого имели успех благодаря подготовленности русской экономической почвы к современным формам промышленности.

О современной модели государственного предпринимательства можно говорить начиная с 60-Х гг. XIX столетия, когда после отмены крепостного права в России сложились условия для индустриализации на основе применения вольнонаемного труда. Комплекс реформ, проведенных «сверху» императорской властью во второй половине XIX в., ускорил процессы назревавших социальных преобразований. Преимущественно натуральный крепостнический уклад стал разлагаться рынком и вытесняться капиталистическим производством. Наметился переход от аграрного общества к индустриальному. Российские власти делали все для быстрого развития экономики. Были приняты меры по защите иностранных инвесторов от возможных политических и иных рисков. Реформы, осуществленные С. Ю. Витте в конце XIX в., заложили правовой и экономический фундамент подъема экономики России, обеспечили создание необходимой для нее финансовой и производственно-хозяйственной структуры - банков, бирж, ярмарок, новых транспортных магистралей, заводов, фабрик и т.п.

М. И. Туган-Барановский отмечал, что «в конце XIX века, как и при возникновении нашей фабричной промышленности при Петре I, русское правительство, поощряя рост фабричного производства, руководствовалось, главным образом, так называемыми „государственными“ соображениями, т.е. стремлением увеличить платежные силы населения для пополнения государственного казначейства. Рост производительных сил есть единственно возможная опора политического могущества» [16, с. 521]. Экономические интересы крупных промышленных и торговых капиталистов играли хотя и важную, но второстепенную роль. Главным действующим лицом отечественной индустриализации было, как, впрочем, и остается, государство. 
Вышесказанное означает, что для российской модели государственного предпринимательства характерна следующая структура иерархии экономических интересов (рис. 4):

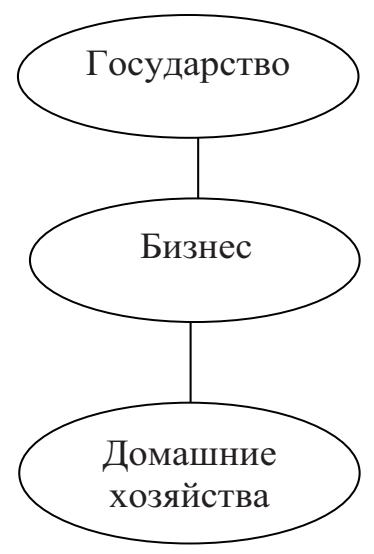

Рис. 4. Российская модель государственного предпринимательства

Исходные теоретические предпосылки российской модели государственного предпринимательства - взаимосвязь хозяйственной и управленческой деятельности государства, иерархическое и финансовое господство государственного аппарата в системе экономических отношений, решающее значение бюджета в экономической жизни страны - подтверждаются анализом исторического опыта.

Два структурных кризиса в ХХ в. предопределили качественные преобразования модели государственного предпринимательства, но при этом не изменили ее структурного уклада.

Первый кризис был спровоцирован участием России с 1914 г. в Первой мировой войне, продолжался до окончания Гражданской войны в 1920 г. и привел к становлению экономики советского, директивно-планового типа. Истоки другого кризиса обнаружились на исходе 1980-х гг. в ходе перестройки централизованно управляемой, казенно-кооперативной экономики СССР в частно-государственное, конкурентно-рыночное хозяйство. Сравнение социально-экономических потрясений в начале и конце века позволяет лучше понять закономерности хозяйственного развития нашей страны.

Российские реформы конца 80-х - 90-х гг. XX в. имели много общих моментов с преобразованиями народной жизни периода 1914-1920 гг. Повторяемость событий показывает закономерности перехода от одной парадигмы хозяйствования к другой в условиях революционной ломки всех общественных устоев. Превышение государственным аппаратом допустимого, по- рогового воздействия на экономику сопровождалось ее деградацией и приводило к революционным трансформациям. Так было в обоих рассматриваемых системных кризисах [17, с. 39]. Структурные кризисы начала и конца XX в. говорят о наличии инверсий - возвратном движении в проведении реформ отечественной экономики, наблюдаемые уже более двух веков в российской истории [14, с. 196].

Для российской модели государственного предпринимательства, занимающей полупериферийное место в мировой иерархии, характерны «маятниковые» движения, наиболее четко проявляющиеся в рамках «векового цикла» Ф. Броделя $[18$, с. 73$]$ и «системных циклов накопления» Дж. Арриги. На повышательной волне происходило приближение России к центру мировой экономики, на понижательной наша страна скатывалась к периферии.

Так, в рамках цикла американской гегемонии, пик которой пришелся на 1960-е гг., российская экономика пережила расцвет. Россия (СССР) была второй мировой державой, вплотную приблизившись к странам центра, показывая значительные темпы роста ВВП, производительности труда, уровня промышленного производства. Удельный вес России в мировом промышленном производстве приближался к пятой части промышленного производства мира. Росли качественные характеристики производительности труда [19].

Очередная волна, качнувшая «маятник» в сторону периферии, приходится на конец 1970-х - начало 1980-х гг. Именно с этого времени, по мнению ряда отечественных специалистов, занимающихся анализом долгосрочных трендов макроэкономической динамики России, начался процесс деиндустриализации, в результате которого наша страна стала скатываться «вниз» к периферии.

Об этом могут свидетельствовать такие данные, как снижение производительности труда в российской экономике, устаревание технологической структуры, несовпадение структуры занятости с квалификационно-образовательной структурой населения экономики, что породило отток высококвалифицированной рабочей силы. Начала нарастать степень отставания технологического уклада от лидирующей группы, что стало причиной нарастания технологического разрыва от стран-лидеров [14, с. 211-212].

\section{Заключение}

Исследование современных процессов мирового хозяйства заполняет пробел в теории и позволяет с единых методологических позиций изучить функционирование экономических 
систем с учетом статусного положения страны в рамках международного разделения труда. Модели государственного предпринимательства являются инструментом анализа политики государственного предпринимательства в экономической системе страны, они имеют устойчивую структуру, соответствующую положению страны в рамках миросистемы.

Российской экономике на протяжении уже нескольких столетий присущи следующие черты: низкая производительность общественного труда, невысокие денежные доходы и слабая покупательная способность населения, неразвитость рыночных институтов, ограниченность торгового и денежного оборота, относительный избыток природных компонентов производительных сил в сравнении с накопленными капитальными благами.

Россия в XXI в., как и сто лет назад, остается полупериферийной страной, основным источником доходов которой является экспорт ресурсов, а движущим субъектом хозяйственных преобразований выступает государство.

\section{Список литературы}

1. Черемисинов Г. А. Государственное предпринимательство в годы нэпа (1921-1932 гг.) : автореф. дис. ... д-ра экон. наук. Волгоград, 2003. 39 с.

2. Черемисинов Г. А. Парадигма директивно-плановой экономики : российский опыт хозяйственных преобразований : в 2 ч. Саратов, 2012. Ч. 1.348 с.

3. Черемисинов Г. А. Парадигма директивно-плановой экономики: российский опыт хозяйственных преобразований : в 2 ч. Саратов, 2013. Ч. 2. 460 с.

4. Валлерстайн И. Анализ мировых систем и ситуация в современном мире. СПб., 2001. 416 с.

5. Валлерстайн И. Миросистемный анализ : Введение. M., 2006. 248 c.
6. Райнерт Э. Как богатые страны стали богатыми и почему бедные страны остаются бедными. М., 2011. $348 \mathrm{c}$.

7. Арриги Дж. Долгий $\mathrm{XX}$ век : Деньги, власть и истоки нашего времени. М., 2006. 472 с.

8. Социально-экономические модели и путь России : в 2 кн. М., 2005. Кн. 1.911 с.

9. Айвазов А. Э. Периодическая система мирового капиталистического развития. URL: http://ajvazov. ru/articles/periodicheskaya-sistema-mirovogo-kapitalisticheskogo-razvitiya.html (дата обращения: 10.04. 2012).

10. Арриги Дж. Адам Смит в Пекине : Что получил в наследство XXI век. М., 2009. 456 с.

11. Обухов Н. Уроки Бреттон-Вудской валютно-финансовой системы // Экономист. 2008. № 11. С. 83-92.

12. Абдулгамидов Н., Губанов С. Двойные стандарты однополюсно глобализации // Экономист. 2002. № 12. C. 20-38.

13. Ершов М. В. Мировой экономический кризис. Что дальше? М., 2011. 295 с.

14. Рязанов В. Т. Хозяйственный строй России : на пути к другой экономике. СПб., 2009. 463 с.

15. Туган-Барановский М. И. Основы политической экономики. Пг., 1917. 540 с.

16. Туган-Барановский М. И. Избранное. Русская фабрика в прошлом и настоящем. Историческое развитие русской фабрики в XIX веке. М., 1997. 735 с.

17. Черемисинов Г. А. Государственное предпринимательство как типологический признак развития экономики России : теоретико-методологический аспект // Изв. Сарат. ун-та. Нов. сер. Сер. Экономика. Управление. Право. 2007. Т. 7, вып. 1. С. 31-44.

18. Бродель $Ф$. Время мира. Материальная цивилизация, экономика и капитализм, XV-XVIII вв. : в 3 т. T. 3. M., $1992.678 \mathrm{c}$.

19. Хазин М. Сравнительные данные по экономике СССР и США. URL: http://worldcrisis.ru/crisis/1154149 (дата обращения: 20.10.2013).

\title{
World-system Approach to the Classification of the Models of Governmental Entrepreneurship
}

\author{
I. O. Pugachev \\ Saratov State University, \\ 83, Astrakhanskaya, Saratov, 410012, Russia \\ E-mail: ilya_ov@mail.ru
}

Introduction. Model governmental entrepreneurship due to historical conditions of development, geographical location and the national specificities of countries. Research methodology. Governmental enterprise plays a key role in the concept of world-system analysis. Model governmental enterprise entrepreneurship determines the place of the governmental in the economic system and is determined by the country's position in the international division of labor along the axis: power-hegemon - center - semi-periphery - periphery. Results of the study. The European model of governmental entrepreneurship - the model of the center of world-system. It is based on the terms for the fair allocation of revenues between the governmental, business and households. The USA, as the leader of world economy is a model of of governmental entrepreneurship, based on revenue from domestic sources and external sources, putting a monetary operation of the rest of the country. The model of governmental entrepreneurship of the countries of the periphery supply of economic resources in the regions, higher hierarchy in the global division of labor. Intermediate place between the American model of governmental entrepreneurship and model periphery countries occupied by the semi-periphery, including the Russian model of economy. Conclusion. Russia remains a semi-peripheral country with an exceptionally strong influence on the economy of the governmental entrepreneurship.

Key words: world-systems analysis, model of a governmental entrepre, European economy, US economy, Russia's economy. 


\section{References}

1. Cheremisinov G. A. Gosudarstvennoe predprinimatel'stvo $v$ gody njepa (1921-1932 gg.): avtoref. dis. doct. ekon. nauk [Public enterprise in the years of the NEP (1921-1932). Dr. econ. sci. thess diss.]. Volgograd, 2003. 39 p.

2. Cheremisinov G. A. Paradigma direktivno-planovoy ekonomiki: rossiyskiy opyt hozyaystvennyh preobrazovaniy: $v 2 \mathrm{ch}$. [Paradigm policy-planned economy: the Russian experience of economic transformations: in 2 pt.]. Saratov, 2012. Pt. 1. 348 p.

3. Cheremisinov G.A. Paradigma direktivno-planovoy ekonomiki: rossiyskiy opyt hozyaystvennyh preobrazovaniy: $v 2 \mathrm{ch}$. [Paradigm policy-planned economy: the Russian experience of economic transformations: in 2 pt.]. Saratov, 2013. Pt. 2. 460 p.

4. Vallerstayn I. Analiz mirovyh sistem i situatsiya v sovremennom mire [The analysis of world systems and the situation in the modern world]. St.-Petersburg, 2001. $416 \mathrm{p}$.

5. Vallerstayn I. Mirosistemnyj analiz: Vvedenie [Worldsystems analysis: an Introduction]. Moscow, 2006. $248 \mathrm{p}$.

6. Raynert E. Kak bogatye strany stali bogatymi i pochemu bednye strany ostayutsya bednymi [How rich countries got rich... And why poor countries stay poor]. Moscow, 2011. 348 p.

7. Arrigi Dzh. Dolgiy XX vek: Den'gi, vlast' $i$ istoki nashego vremeni [The long twentieth century: money, power and the origins of our time]. Moscow, 2006. $472 \mathrm{p}$.

8. Sotsial'no-ekonomicheskie modeli i put'Rossii: $v 2 \mathrm{kn}$. [Socio-economic model and way of Russia]. Moscow. 2005. Pt. 1. 911 p.

9. Ayvazov A. E. Periodicheskaya sistema mirovogo kapitalisticheskogo razvitiya (Periodic system of world capitalist development). Available at: http:// ajvazov.ru/articles/periodicheskaya-sistema-mirovogokapitalisticheskogo-razvitiya.html (accessed 10 April 2012).
10. Arrigi Dzh. Adam Smit v Pekine: Chto poluchilv nasledstvo XXI vek [Adam Smith in Beijing: What have inherited the XXI century]. Moscow, 2009. 456 p.

11. Obuhov N. Uroki Bretton-Vudskoy valyutno-finansovoy sistemy [The lessons of Bretton woods monetary system]. Ekonomist, 2008, no. 11, pp. 83-92.

12. Abdulgamidov N., Gubanov S. Dvoynye standarty odnopolyusno globalizatsii [Double standards unipolar globalization]. Ekonomist, 2002, no. 12, pp. 20-38.

13. Ershov M. V. Mirovoy ekonomicheskiy krizis. Chto dal'she? [The World economic crisis. What's next?]. Moscow, 2011. 295 p.

14. Ryazanov V. T. Xozyajstvennyj stroj Rossii: na puti $k$ drugoj e'konomike [The economic structure of Russia: on the path to another economy]. St.-Petersburg, 2009. 463 p.

15. Tugan-Baranovskij M. I. Osnovy politicheskoj ekonomiki [Principles of political economy]. Petrograd, 1917. $540 \mathrm{p}$.

16. Tugan-Baranovskiy M. I. Izbrannoe. Russkaya fabrika v proshlom i nastoyaschem. Istoricheskoe razvitie russkoy fabriki v XIX veke [Favorites. Russian factory in the past and the present. The historical development of the Russian factory in XIX century]. Moscow, 1997. $735 \mathrm{p}$.

17. Cheremisinov G. A. Gosudarstvennoe predprinimatel'stvo kak tipologicheskij priznak razvitija jekonomiki Rossii: teoretiko-metodologicheskij aspekt [Govemental enterprishup as a sign of typological development of the Russian economy: theoretical and methodological aspects]. Izv. Saratov Univ. New Ser. Ser. Economics. Management. Law. 2007, vol. 7, iss. 1, pp. 31-45.

18. Brodel' F. Vremya mira. Material'naya tsivilizatsiya, ekonomika i kapitalizm, XV-XVIII vv.: v 3 t. [The time in the world. Material civilization, economy and capitalism, the XV-XVIII centuries: in 3 vol.]. Vol. 3. Moscow, 1992. 678 p.

19. Hazin M. Sravnitel'nye dannye po ekonomike SSSR $i$ SShA (Comparative data on economy of the USSR and the USA). Available at: http://worldcrisis.ru/crisis/1154149 (accessed 20 October 2013). 